\title{
Russian History
}

The Dryden Press wishes to announce an exciting array of new and recent books in Russian history:

Basil Dmytryshyn, Portland State University Imperial Russia A Source Book 1700-1917, Second Edition. February 1974, 512 pages, $\$ 6.00$.

The appeal of this best selling volume of primary source material has now been enhanced by the addition of the texts of twenty-five major treaties the government of Imperial Russia negotiated with its neighbors.

Virgil Medlin, Oklahoma City University

The Russian Revolution

(A European Problem Study) October 1, 1973, 198 pages, \$3.00.

A collection of secondary sources dealing with the nature and causes of the Russian Revolution.

Massimo Salvadori, Smith College

The Rise of Modern Communism,

Third Edition (A Berkshire Study in European History) Spring 1974, 224 pages, $\$ 3.00$.

An updating of Salvadori's major study of the development of the Communist movement in the Twentieth Century.

\section{Available Now for Your Spring Courses:}

Basil Dmytryshyn: Medieval Russia, Second Edition, 1973, \$4.95

Berkshire Studies:

Arthur Adams: Stalin and His Times, 1973, \$3.25

Melvin Wren: The Western Impact on Tsarist Russia, 1971, $\$ 3.00$

European Problem Studies:

Daniel Brower: The Soviet Experience, Success or Failure?, 1971, $\$ 3.00$

Terence Emmons: The Emancipation of the Russian Serfs, 1970, $\$ 2.60$

Robert McNeal: Russia in Transition 1905-1914, 1969, $\$ 3.00$

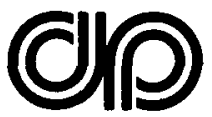

The Dryden Press

A division of Holt, Rinehart and Winston, Inc. 901 North Elm Street, Hinsdale, Illinois 60521 


\section{IN FORTHCOMING ISSUES}

W. Bruce Lincoln, "N. A. Miliutin and the St. Petersburg Municipal Act of 1846: A Study in Reform Under Nicholas I"

Gary Kern, "Solzhenitsyn's Portrait of Stalin"

Alexander Gerschenkron, "Soviet Policies Versus International Cartels:

Four Historical Case Studies"

Philip J. Adler, "Habsburg School Reform Among the Orthodox Minorities, $1770-1780$ "

Norman E. Saul, "A Russian 'Yankee Doodle'”

Andor Klay, "Hungarian Counterfeit Francs: A Case of Post-World War I Political Sabotage"

Betty M. Unterberger, "The Arrest of Alice Masaryk"

Russell Zguta, "The Pagan Priests of Early Russia: Some New Insights"

Lee Congdon, "Endre Ady's Summons to National Regeneration in Hungary, 1900-1919"

Sheila Fitzpatrick, "The 'Soft' Line on Culture and Its Enemies: Soviet Cultural Policy, 1922-1927"

William L. Mathes, "Russian Collections in Libraries and Archives of Warsaw"

Elizabeth C. Shepard, "Pavlov's 'Demon' and Gogol's 'Overcoat' "

\section{CHANGE OF ADDRESS}

Members and subscribers are asked to send prompt notification of change of address, giving new and old addresses and zip code numbers, to American Association for the Advancement of Slavic Studies, 190 West 19th Avenue, Ohio State University, Columbus, Ohio 43210.

\section{NOTICE}

Unsolicited manuscripts must be accompanied by a self-addressed, stamped envelope. They should be mailed to The Editor, Slavic Review, Thomson Hall, University of Washington, Seattle, Washington 98195. 


\section{MANDELSTAM}

\section{CLARENCE BROWN}

The first critical study of the life and works of the great Russian poet. Professor Brown tells as much as will probably ever be known about Mandelstam's early years in the intellectual world of prerevolutionary St. Petersburg. His treatment of Mandelstam's poetry is a full and thoughtful criticism, supported by extensive quotations in Russian and in English translation.

$\$ 13.95$

\section{THE RUSSIAN CONSTITUTIONAL EXPERIMENT}

\section{Government and Duma 1907-1914}

\section{GEOFFREY A. HOSKING}

"This book will be read with pleasure and profit by students of Russian czarism's last years. . . . Hosking analyzes dispassionately and, in my view, fairly, the substance, course, and achievement of Stolypin's notorious 'counterrevolution'. . . . This is a valuable addition to Russian historiography."-Library Journal $\$ 18.50$

\section{LEON TROTSKY AND THE POLITICS OF ECONOMIC ISOLATION}

\section{RICHARD B. DAY}

Professor Day utilizes previously unexploited material from the Trotsky Archives in his controversial examination of Soviet Russia from 1917 to 1927 . He concentrates on Russia's economic isolation and analyzes two vital factors: War Communism from 1918 to 1921 and the Trotsky-Stalin debate over the concept of Socialism in one country.

$\$ 10.95$

\section{CZECHOSLOVAKIA BEFORE MUNICH}

\section{The German Minority Problem}

\section{and British Appeasement Policy}

\section{J. W. BRUEGEL}

In this chronological account based on extensive public and private records, Dr. Bruegel analyzes internal and international CzechGerman relations and British foreign policy from 1918 on, shedding new light on the Munich crisis, the role of Chamberlain and the diplomatic staff and the ultimate sacrifice of Czechoslovakia. $\$ 14.95$

\section{Cambridge University Press}

32 East 57th Street, New York, N.Y. 10022 